\author{
UNITED STATES \\ DEPARTMENT OF THE INTERIOR \\ GEOLOGICAL SURVEY
}

\title{
CORRELATION CHARACTERISTICS OF SURFICIAL DEPOSITS WITH A DESCRIPTION OF SURFICIAL STRATIGRAPHY IN THE NEVADA TEST SITE REGION
}

D. L. Hoover, ${ }^{1}$ W C Swadley, ${ }^{1}$ and A. J. Gordon ${ }^{2}$

${ }^{1}$ U.S. Geological Survey, Denver, Colo.

${ }^{2}$ Formerly Fenix \& Scisson, Inc., Las Vegas, Nev. 


\section{CONTENTS}

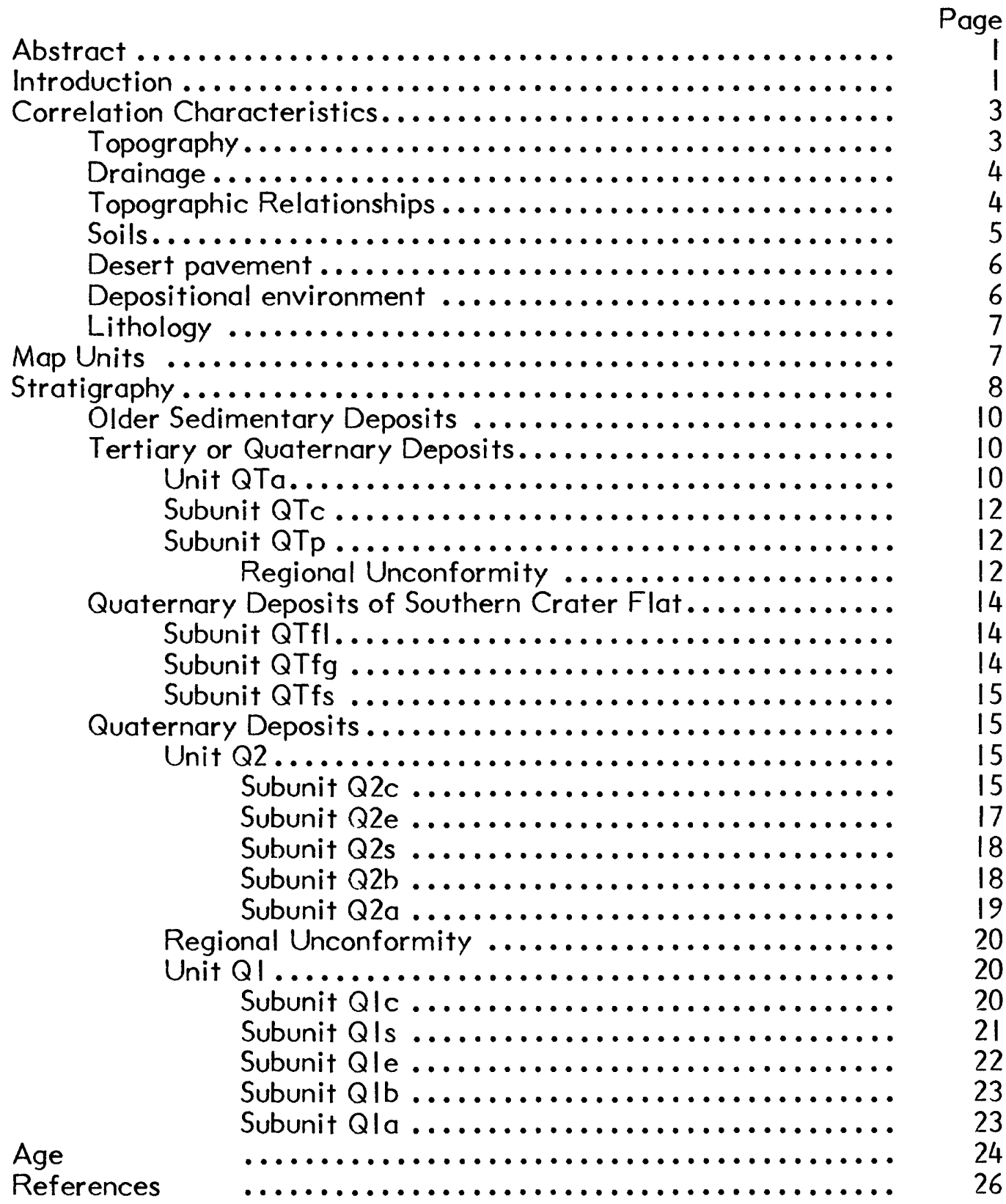




\section{ILLUSTRATIONS}

Figure 1.---Index map of Nevada Test Site region showing

Page areas where detailed mapping surficial

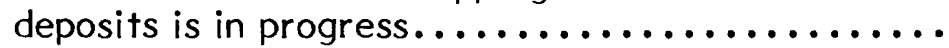

2.--Major surficial units present in the NTS region.

3.--Schematic cross section along contour showing deposition of pediment gravel deposited in shallow lows on pediment beveled on unit $J$ of Eleana Formation and overlain by unit

QTa

TABLES

Table 1. Correlation characteristics of surficial

deposits. 


\title{
CORRELATION CHARACTERISTICS OF SURFICIAL DEPOSITS WITH A DESCRIPTION OF SURFICIAL STRATIGRAPHY IN THE NEVADA TEST SITE REGION
}

\author{
By \\ D. L. Hoover, W C Swadley, and A. J. Gordon
}

ABSTRACT

\begin{abstract}
Surficial deposits in the Nevada Test Site region have been correlated between valleys using correlation characteristics. Correlation characteristics include topography, drainage, topographic relationships, soils, desert pavement, depositional environment, and lithology. Stratigraphic units include Pliocene or Pleistocene debris flows, Pliocene or Pleistocene lakebeds, bedded gravels, and spring deposits, and two Quaternary fluvial and eolian units. The Pliocene or Pleistocene debris flows and the two Quaternary units are separated by regional unconformities. Each of the Quaternary units contains five subunits. The Bishop ash and several radiometric dates have been used to determine the age of the Quaternary units.
\end{abstract}

\section{INTRODUCTION}

This report provides a basis for correlating surficial deposits--correlation characteristics--and describes the stratigraphy of surficial deposits in the Nevada Test Site (NTS) region in terms of these characteristics. The report should serve as a manual for mapping, as a data source for Quaternary studies, and as a summary of existing ideas about Quaternary history in the NTS region. The stratigraphic studies presented in this report are part of the geologic investigations for a nuclear waste repository site in the NTS region (fig. I). Stratigraphic correlation is needed to date faults and to interpret the late Tertiary and Quaternary history. Some of the characteristics of surficial deposits will provide paleoclimatic data needed as basic data for the interpretation of the paleohydrologic regime.

Surficial deposits in the Great Basin have been correlated on the basis of intercalation with lake deposits, volcanic rocks, or glacial deposits, by soil identification, by geomorphic similarities, by radiometric age dating and by paleontological and archaeological evidence. Morrison (1968) thoroughly reviewed the advantages and disadvantages of the various correlation methods used for Quaternary deposits in general. He advocated using soils, preferably buried soils, as time-stratigraphic horizons for correlation (Morrison, 1967).

All of these methods have serious disadvantages when correlating surficial deposits across large areas that include several basins. Characteristics needed for correlation by the methods previously noted are absent in many areas, require special techniques, or require specialized knowledge.

Quaternary alluvium in the Vidal area of California was mapped on the basis of descriptive correlation characteristics (Bull, 1974; Carr, Dickey, and Bull, 1980). Although individual characteristics varied considerably within some units, the combination of the characteristics was sufficient to consistently identify a map unit. The general and specific basis for correlation was not stated, but the descriptions of Bull (1974) make it obvious that correlation characteristics include climatic, topographic, and lithologic factors. This report formalizes and expands the correlation characteristics outlined by these authors. 


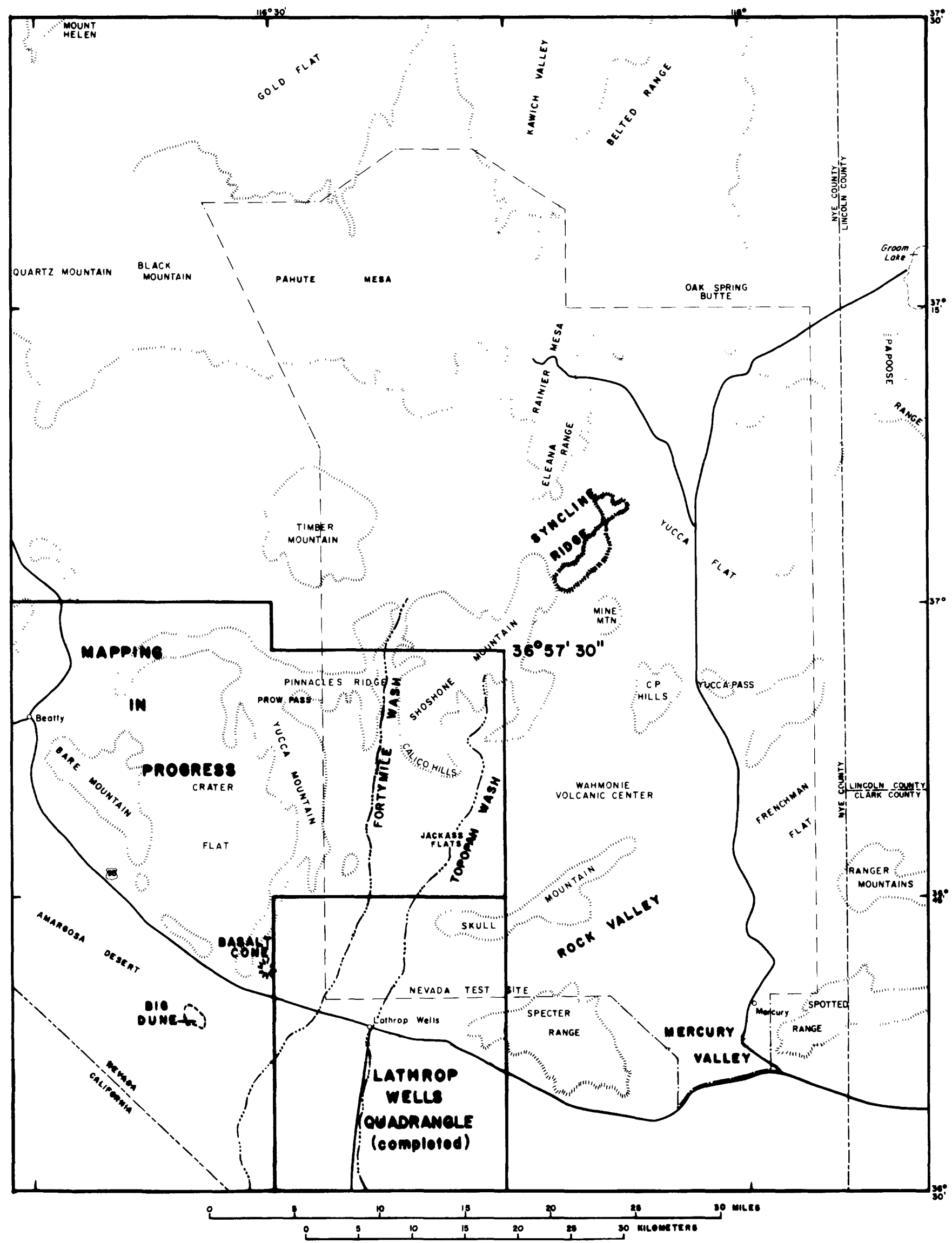

Figure 1.--Index map of Nevada Test Site region showing areas where detailed mapping of surficial deposits is in progress. 


\section{CORRELATION CHARACTERISTICS}

The normal methods of correlation--lateral continuity, lithologic identity, superposition, and structural relationships (Krumbein and Sloss, 1955)--are either lacking, identical in different units, or greatly variable in surficial deposits. Climatic, topographic, and lithologic factors can furnish the characteristics to correlate surficial deposits. Ideally, one characteristic should uniquely identify a map unit, but similarity of source materials or processes, variation of processes in time or location, and convergence toward identity of characteristics in time or location result in depositional units that are rarely unique in a single characteristic. Multiple correlation characteristics can definitively identify a map unit because the probability is high that variations in time or location of two or more characteristics of one unit will differ from variations of the same characteristics of a different unit.

The characteristics on which correlation of surficial deposits in the NTS area are based are shown in table I. Two or three of these characteristics are usually enough to identify a stratigraphic unit. Lack of exposure or overlap in the variation of one or more correlation characteristic between map units require the use of different characteristics to identify a map unit at different locations. For instance, the presence of numerous boulders larger than $1 \mathrm{~m}$ in diameter on rounded, elongate hills identifies the oldest depositional unit, but other map units occasionally have boulder concentrations of similar size. Similarly, the oldest depositional unit in places may have a dissected flat surface and lack boulders, characteristics common to younger units, but the presence of caliche more than 2 $m$ thick and deep dissection on interfluves between major drainages identifies the oldest unit.

Although descriptive characteristics based on climatic, topographic, and lithologic factors have been used in correlating glacial and other Quaternary deposits (Birkeland and others, 1979), the characteristics for correlation in surficial deposits have not been previously defined. These characteristics are defined here so that correlation will not depend on definitions inferred from descriptions.

\section{Topography}

Topography includes curvature along the contour (macrotopography) and local relief (microrelief). Macrotopography is the curvature that can be seen along the contour for approximately $300 \mathrm{~m}$. Curvature in the NTS region is the result of depositional form, dissection, and smoothing by soil creep and sheetwash. Macrotopography is described as flat, slightly convex, convex, and highly convex or well rounded.

Microrelief refers to relief within a radius of 10 to $20 \mathrm{~m}$. Microrelief does not include slope relief, boulders, or recent eolian accumulations around shrubs. Relief is described as less than $0.2 \mathrm{~m}, 0.2-0.5 \mathrm{~m}$, and greater than $0.5 \mathrm{~m}$ in the NTS region, but other divisions may be needed elsewhere. Microrelief is a measure of smoothing of a surface after active deposition or erosion ended. Bar and swale microrelief identifies the youngest alluvial deposits in the NTS region, but older deposits in other areas may also have bar and swale microrelief. 
Table I.--Correlation characteristics of surficial deposits

1. Topography

A. Macrotopography ( $300 \mathrm{~m}$ along contour)

B. Microrelief ( $10-20 \mathrm{~m}$ radius)

II. Drainage

A. Pattern and development direction

B. Cross section shape

C. Depth

III. Topographic relationships

IV. Soils

A. A and B horizons

1. Color

2. Clay, carbonate, and silica content

c. Pedogenic caliche ( $\mathrm{C}$ or $\mathrm{K}$ horizons)

I. Stage

2. Thickness

V. Desert pavement

A. Packing and sorting

B. Maximum fragment size

C. Varnish color and luster

VI. Depositional environment

VII. Lithology

A. Ratio of clast lithologies

B. Maximum fragment size and frequency

C. Sand and clay content

D. Color

\section{Drainage}

Drainage includes drainage patterns, direction of pattern development, shape of the drainage cross section, and the depth of drainage. Patterns at NTS are dendritic, subparallel to parallel, and anastomosing or braided. In the youngest deposits drainage is developing downslope. On older deposits drainage developed upslope and is being extended upslope by modern erosion. Drainage cross sections are vertical to steeply sloping, gently rounded and highly rounded. Most gently rounded drainages contain incised modern drainages that may have destroyed the gently rounded shape in the lower reaches.

Drainage depths vary greatly and are dependent on drainage basin size and relief, distance from the ranges, and on tectonic activity. Within individual structural blocks, which are defined by extension into the valleys of structures in the ranges, drainage depths are consistent for each stratigraphic unit located the same distance from the range/valley boundary.

\section{Topographic Relationships}

Successively lower deposits are successively younger in basins that have exterior drainage. These basins have a constant base level and erosion predominates over deposition. The closed basins of the Great Basin have a rising base level because of valley filling. Erosion predominates in the ranges; deposition predominates in the valleys. Younger deposits are usually lower in the ranges, and higher in the valleys. At a given distance from the boundary between a range and a valley and within the same structural block, the topographic relationship between two units is constant for drainage basins of similar size. 
Rates of deposition change both within valleys and between valleys. Changes in the depositional rate cause differences in the topographic relationships of depositional units. The position where a younger unit changes from lower to higher than an older unit can change within 1 to $2 \mathrm{~km}$ down a valley slope from the range or it may change within the range. Drainage basin morphometry and tectonism are the usual causes of changes in topographic relationships. Climatic, lithologic, and structural differences can also be causes of changes in topographic relationships.

\section{$\underline{\text { Soils }}$}

Soil characteristics include color and clay, silica content of A and B horizons, and stage and thickness of pedogenic caliche. Soils with well-developed $A$ and $B$ horizons are seen only on deposits of intermediate and older age. Pedogenic caliche may be either a $C$ or $K$ horizon. $K$ horizons may engulf part of the $B$ horizon. Soils on the youngest deposits are poorly developed. They consist only of $2-10 \mathrm{~cm}$ that is leached of all or most of the carbonate, and thin films of caliche deposited on the bottoms of pebbles in a single layer.

The soils on intermediate or older deposits in the NTS region are polygenetic in that the $A$ horizon has a different parent material and is a different age than $B$, $C$ or $K$ horizons beneath it. The $A$ horizon ranges from 5 to $50 \mathrm{~cm}$ in thickness and is vesicular in the upper 25-50 percent of its thickness. The A horizon consists mostly of silt and very fine grained sand with just enough clay to be noticeable, but not sticky. Fragments coarser than sand are usually present only on slopes greater than 5 percent or where thickness of the A horizon is less than about $20 \mathrm{~cm}$ and the $B$ horizon is absent. Calcium carbonate is usually leached in the upper vesicular part and deposited in the lower nonvesicular part of the $A$ horizon, but the amount of leaching and concentration varies greatly. Contacts with underlying $B, C$, or $K$ horizons are usually sharp except where soil creep has mixed the horizons. Leaching and redeposition of carbonate in the $A$ horizon above a leached $B$ horizon, presence of an $A$ horizon on a $C$ or $K$ horizon where the $B$ horizon has been stripped, and discontinuities in trend-lines of a uraniumseries disequilibrium radiometric date between $A$ and $B$ horizons indicate that the A horizon is much younger than the underlying soil horizons. Uniform mineralogy of the A horizon on parent materials that differ greatly in both composition and relative age indicate that the $A$ horizon is probably eolian in origin.

$B$ horizons are present on deposits of intermediate age and in a few places on the oldest deposits. B horizons range from cambic to argillic. Cambic B horizons have partial to nearly complete leaching of carbonate and varying degrees of clay skin development on sand-sized fragments. Most cambic B horizons are formed from materials that contain mostly sand-sized material. Cambic $B$ horizons range from a reddish yellow (7.5YR 6/6) to a yellowish red (5YR 5/6), but they could more appropriately be termed orangish brown to reddish orange brown. Clay content ranges from very small amounts to noticeable without being sticky. Fragments larger than sand sizes are present only where the horizon is less than $25 \mathrm{~cm}$ thick or where soil creep has been active.

Argillic B horizons are completely leached of carbonate, but may have fractures coated with carbonate and silica. The carbonate of $K$ horizons also engulfs a few centimeters of argillic B horizons at a few locations. Except where the horizon is disturbed by soil creep, argillic B horizons are almost totally clay and silt size. Clay is abundant, but stickiness is dependent on silica content. 
Silica content is high enough in some argillic B horizons to form platy prisms a few centimeters thick and $10-15 \mathrm{~cm}$ across that require hammering to break into small pieces.

Pedogenic caliche ranges from films on the bottoms of pebbles in a single layer to $\mathrm{K}$ horizons several meters thick. Caliche is described in terms of the stages of Gile and others (1966) as Stage I-IV.

Careful examination of caliche is needed to insure that it is pedogenic. Lateral migration of carbonate near steep wash banks and algal(?) caliche deposited in shallow (deflation?) depressions on flat surfaces are often mistaken for Stage IV caliche. Layering, either along bedding planes or within beds, particularly where higher stages sandwich a lower stage, is usually an indication of lateral migration of nonpedogenic carbonate. Where beds can be followed continuously up or downslope, layered caliche can often be seen to thin to nothing along bedding.

\section{Desert pavement}

Desert pavements in the NTS region are formed by a single layer of clasts ranging from $4 \mathrm{~mm}$ in diameter to boulders that rest on soils. The pavements have a smooth surface formed by soil creep and sheetwash. In areas outside the NTS region, soils may be lacking beneath the pavement. Packing of pavements refers to the percent of space occupied by fragments $4 \mathrm{~mm}$ or larger in diameter. Packing is estimated visually and described as loosely packed (less than 50 percent), moderately packed (50-75 percent) and densely packed (greater than 75 percent). Sorting refers to the size distribution of clasts and is a visual estimate of poorly, moderately, or well sorted. Boulders ranging from $0.5 \mathrm{~m}$ to as much as $10 \mathrm{~m}$ in diameter are found on some pavements. Boulders less than $1 \mathrm{~m}$ in diameter may be part of the pavement-forming process, but larger boulders are probably erosional remnants.

Varnish on pavements ranges from brown to black, from dull to shiny, and from films to coatings as much as $2 \mathrm{~mm}$ in thickness. Within a single valley, varnish is relatively uniform on the same unit, but variances between valleys may be large.

Variation in, absence of, or presence of pavements is not sufficient evidence for identification of even major depositional units. Erosion by sheetwash or soil creep on steep slopes can change the appearance of or entirely strip pavements. The exposure of dull orangish-brown varnish films or color banding of varnish that is not subparallel to the ground surface usually indicates a disturbed pavement. Varnish may not be present on some limestone or volcanic pavements, pavements may be disturbed or packing may change on thick soils susceptible to creep. Cleavage of pavement fragments is rare in the NTS region. Occasionally, book cleavage of a few larger fragments of quartzite or limestone is found on older pavements above $1,500 \mathrm{~m}$ in elevation.

\section{Depositional environment}

Deposits during the Quaternary in the NTS region include fluvial deposits of coarse material, fluvial deposits of sand derived from eolian deposits, eolian sheets and dunes, and debris flows. Spring and pond deposits are rare and very small in area. Deposits progress from predominantly debris flows in the oldest 
unit to predominantly fluvial deposits in the youngest units. This progression probably reflects decreasing tectonic relief and indicates that either slope reduction was faster than uplift or that tectonic activity decreased during the Quaternary. In contrast, deposits of intermediate age in Fish Lake Valley on the Nevada-California border are almost entirely debris flows, whereas in the NTS region these deposits contain more fluvial deposits than debris flows. Other postdepositional characteristics are the same in both areas. Characterization of depositional environment can seldom be made from a single outcrop because of the rapid changes of depositional environment in short distances and poor outcrops common to alluvial deposits. Depositional environments are more useful as supporting evidence than for identification of a depositional unit.

\section{Lithology}

Lithologic characteristics are mostly useful as supporting evidence and rarely can be used alone to identify a stratigraphic unit. Lithologic characteristics of a single unit vary within single fans as well as from fan to fan and between valleys. Lithologic characteristics may be needed where other characteristics are lacking or ambiguous.

Depositional units derived from some structural blocks in the ranges may show a progressive change from predominantly Tertiary volcanic rocks to predominantly Paleozoic rocks. This progressive change is the result of sequential erosion. Such changes are useful in identifying a unit in some areas. Sudden changes in lithology may indicate tectonic disturbances, a change in depositional environment, or stream capture.

Fragment size and frequency are distinctive in some units. Boulders with diameters greater than $1 \mathrm{~m}$ characterize the oldest deposits in the NTS region because these deposits are predominantly debris flows. Boulders in younger deposits are mostly less than $1 \mathrm{~m}$ in diameter except in isolated boulder piles near the foot of ranges. Numerous boulders larger than $0.5 \mathrm{~m}$ in diameter may be the only visible evidence of the oldest unit overlain by a thin sheet of a younger unit.

Sand and clay content in locations protected from deposition by surface wash, such as vertical cutbanks, trenches and drill holes, are sometimes useful in identifying older units. Sand and clay content vary too much from place to place and are useful only as supporting evidence for identification.

Color of deposits, as opposed to color of surfaces, is useful where most of the surface-related postdepositional characteristics have been destroyed by erosion. In the NTS region color of deposits changes from light gray or brownish gray in the youngest deposits, to various shades of brown in deposits of intermediate age, to pinkish or reddish shades in the oldest deposits. Colors are useful only in identification of the three major depositional units.

\section{MAP UNITS}

The identification and mapping of alluvial deposits are complicated by three factors: (1) geomorphic surfaces are not coextensive with underlying deposits, (2) surfaces are often much younger than the underlying deposits, and (3) changes from erosional to depositional environments cause differences in character. The first two factors leave the mapper with the problem of whether to map surfaces, deposits, or both. The third factor results in map units that can be separated in 
one area and not in another or a map unit that may be different in age at different locations. The change from an erosional to a depositional environment often results in an unconformity that cannot be identified and in stratigraphic units that cross time lines.

Where surfaces and underlying deposits differ greatly in age and are not coextensive, they should be mapped separately. Where surfaces are generally coextensive with underlying deposits and are confined to a single depositional unit, separate mapping of the surface and the depositional unit will depend on the purpose and scale of mapping. Commonly, a depositional unit and an associated slightly younger surface will be less than 1 or $2 \mathrm{~m}$ in thickness and may cover large areas of a much older unit. The older unit may be exposed and identifiable only in a few drainages. This thin coverage of large areas is equivalent to a pediment covered by an alluvium veneer. The younger unit should be mapped not as a separate unit, but as a dual unit--i.e., younger/older--using the appropriate map symbols.

The disappearance of characteristics differentiating one map unit from another is common to all mapping where facies changes are present. Where two units cannot be differentiated, they should be mapped as a combined unit using a dual symbol-- i.e., younger--intermediate.

Mapping of Quaternary surficial units in the NTS region is difficult because of lithologic similarities of map units and the fact that the map units are hybrids of time-stratigraphic and rock-stratigraphic units (see Birkeland and others, 1979, for discussion of similar problems of stratigraphic identification in glacial deposits). Space and time scales of Quaternary units are much smaller and shorter than those of older rocks. Depositional and postdepositional environments have only small variances that cause only small differences in individual correlation characteristics. Failure to recognize these differences between Quaternary and older rock units is often the cause for unidentified boundaries between Quaternary units.

\section{STRATIGRAPHY}

Three major surficial units separated by regional unconformities, are present in the NTS region (fig. 2). The upper two units, QI and Q2, are Quaternary in age; the lower unit, QTa, may be either Quaternary or Tertiary in age. A fourth major unit, lake deposits of the Amargosa Desert, contains a Pliocene ash bed, but may be of Quaternary age in the upper part.

Because no depositional hiatuses have been found in the oldest unit, it is termed simply Quaternary-Tertiary alluvium (QTa). Alluvium is normally defined as stream deposits. In this report it is used as a general term for any deposit that involves water transport. Alluvium includes debris flows, stream deposits and sheet wash ranging from gravel to sand in size. Local facies, colluvium and pediment gravel, have been mapped separately in two small areas.

Deposits younger than QTa are designated by a number to indicate the major stratigraphic unit and by a letter to indicate an alluvial subunit. Both numbers and letters increase with age. Subunits are separated by unconformities, but these unconformities are not recognizable at all localities. Eolian and fluvial sand deposits are designated by appropriate letters. Unit Q2 includes five subunits, but three additional subunits of uncertain age may belong in unit Q2. Unit Q1 contains five subunits. 


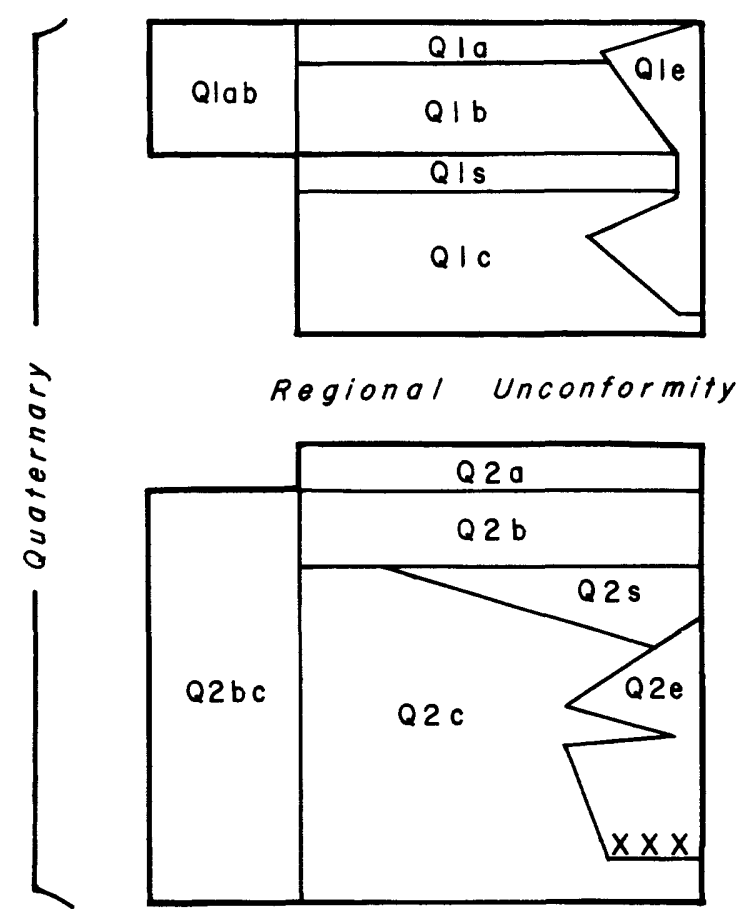

Q1ab - Subunits $a$ and $b$, undifferentiated

Q1a - Coarse fluvial deposits

Q1b - Coarse fluvial deposits and debris flows

Q1s - Fluvial sand sheets

Qle - Eolian dunes and sheets

Q1c - Coarse fluvial deposits, minor debris flows

Q2a - Local debris flows

Q2bc - Subunits b and c, undifferentiated

Q2b - Strath terraces

Q2s - Fluvial sand sheets

Q2e - Eolian dunes and sheets;

$X X X$ - Bishop ash

Q2c - Coarse fluvial deposits, fluvial sands and minor debris flows

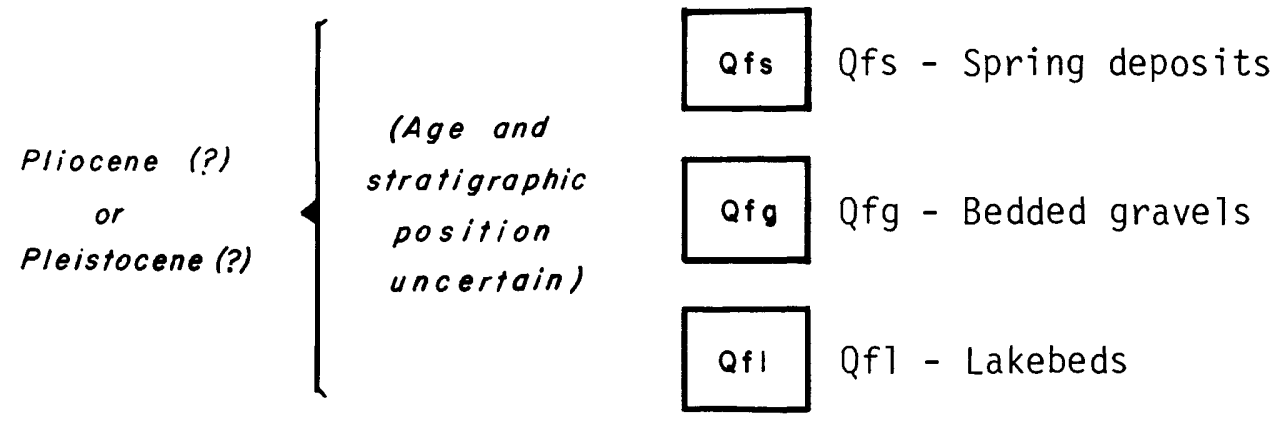

Regional Unconformity

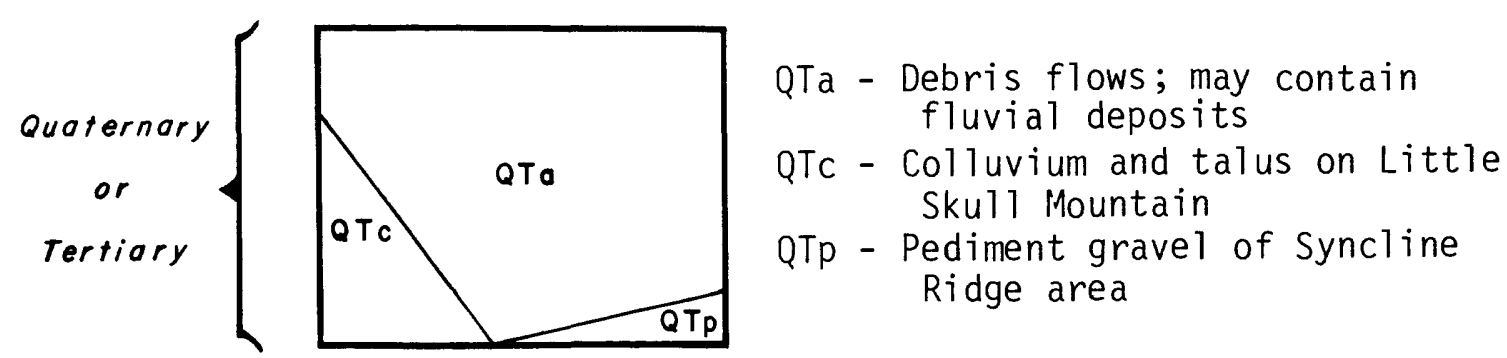

Regional (?) Unconformity

Figure 2.--Major surficial units present in the NTS region. 


\section{Older Sedimentary Deposits}

Tertiary alluvium, lakebeds, and sandstone are overlain by Quaternary alluvium at several locations in the NTS region. Their major differences are presented here to help differentiate them from Quaternary alluvium. Miocene lakebeds and tuffaceous sandstones are present in the basal part of the Tertiary section in much of southern Nevada. Most of these deposits are pastel in color and contain mostly clay- to silt-size material. Miocene and Pliocene alluvium and colluvium are intercalated with volcanic rocks. The outcrops are generally small and monolithologic. Quaternary deposits a few meters thick or Quaternary surfaces may overlie these older deposits. Caliche is more than $2 \mathrm{~m}$ thick in Tertiary alluvium, generally thicker than most of the Quaternary deposits. Miocene or Pliocene deposits that contain well-rounded pebbles to boulders deposited by a river have been found in the Lathrop Wells area. This deposit includes volcanic rocks not known in the NTS region, and forms a rounded ridge containing a pebbly sandstone at the base of the ridge.

Pliocene or Pleistocene lake deposits crop out in much of the Amargosa Desert south and southwest of NTS. These lake deposits are shades of white, pale buff or pale green, well bedded, and contain thin limestones. Fragments larger than sand sizes are present only as scattered pebbles in the limestone at the top of the lake deposits. The lake deposits underlie unit QTa. An ash bed near the middle of the deposits has been radiometrically dated as 3 m.y. old. Because the age of the upper beds and the lower age limit of unit QTa are not known, the lakebeds may be partly Quaternary in age. They are mapped in the Lathrop Wells quadrangle (Swadley, in press) as unit QTId.

\section{Tertiary or Quaternary Deposits}

\section{Unit QTa}

Most of unit QTa crops out adjacent to the ranges. In a few valleys scattered outcrops are located at distances of several kilometers from the ranges. Unit QTa lies on bedrock where the base is exposed near the ranges. In the Lathrop Wells quadrangle the unit overlies Tertiary river gravels and remnants of basalt hills at distances of $5-10 \mathrm{~km}$ from the nearest range. Data from drill holes in Yucca Flat indicate that unit QTa overlies older alluvium in the deeper parts of the valleys. The unit fills small basins in the range margins. In a few areas uplifted by post-QTa faulting, unit QTa is present as remnants clinging to steep slopes of the ranges. The maximum thickness found in a drill hole was $32 \mathrm{~m}$, but it may be as much as $150 \mathrm{~m}$ thick.

Unit QTa forms long, parallel ridges that are convex or convexo-concave. These ridges are called whalebacks in other areas of the Great Basin ( $F$. F. Peterson, oral commun., 1979). Ridges wider than about $50 \mathrm{~m}$ are flat on top. Within a structural block, ridge tops are usually concordant. In the Yucca Mountain and Crater Flat areas, the unit forms large, flat areas covered by a veneer of Q2 deposits or by Q2 soils. Microrelief is less than $0.2 \mathrm{~m}$. Residual boulders from 0.5 to $10 \mathrm{~m}$ in diameter commonly litter the surface. These boulders were left after erosion of $25-100 \mathrm{~m}$ of unit QTa above the present surface.

Drainage is parallel or subparallel or, less commonly, parallel dendritic with well-rounded valleys. The valleys are roughly equal to or slightly greater in width than the ridges and 8-25 $\mathrm{m}$ deep with steep sides. 
QTa drainage developed upslope, and where it has not been destroyed by younger erosion, the upper parts of these drainages are gently sloping and rounded.

Unit QTa is higher in altitude than younger deposits except for Q2 sand dunes. In tectonically active areas, the unit dips rapidly beneath the younger units. In small intrarange valleys, unit QTa may be completely stripped, overlain by younger units or at lower elevations than in the adjacent major valleys. In tectonically stable areas the surface of unit QTa may be overlain by a thin blanket of unit Q2 for distances as great as $15 \mathrm{~km}$.

Soils on unit QTa are probably $Q 2$ in age, but are described here because of their association with unit QTa and their differences from younger $Q 2$ soils. Most of the evidence for events between deposition of unit QTa and unit $Q 2$ has been removed by erosion. After deposition of unit QTa, a significant thickness was stripped to a planar surface. Evidence for this stripping includes residual boulders as much as $10 \mathrm{~m}$ in diameter on narrow ridge tops, concordant ridgetops or dissected surfaces above Q2 surfaces, benches or slope changes in range valleys that are higher than, but parallel to, the ridgetops or surfaces on unit QTa, and discontinuous caliche lines in the ranges near QTa outcrops. The benches and slope changes in range valleys and the caliche lines indicate that $25-100 \mathrm{~m}$ of unit QTa were eroded.

Following stripping of unit QTa, a soil with a well-developed $B$ and $K$ horizon was formed on the planar surface. Later, dissection removed virtually all evidence of the soil except the $K$ horizon and a few small remnants of the $B$ horizon. The $K$ horizon is Stage IV and $3 \mathrm{~m}$ or more in thickness. Thickness is difficult to determine because unit QTa is poorly exposed. Where pavement is disintegrating, plates of laminar caliche from the top of the $K$ horizon litter the pavement. The plates are $10-20 \mathrm{~cm}$ across, roughly square or rectangular and $0.5-$ $1.5 \mathrm{~cm}$ thick. The only location where a nearly complete section of the $B$ horizon can be seen is at the northeast corner of Yucca Mountain just south of Yucca Wash. At this location the B horizon is $25-40 \mathrm{~cm}$ thick and consists of darkreddish-brown (IOYR 3/4) clay and silt that increases in silica content downward. Near the base of the $B$ horizon, opal and chalcedony plates are irregularly spaced and parallel to the surface. The plates are less than $1 \mathrm{~cm}$ in thickness and 10 to $15 \mathrm{~cm}$ in diameter.

The A horizon of QTa soils is the same eolian A horizon as on unit Q2.' The A horizon is between pale yellowish brown (IOYR 6/2) and light brownish gray (5YR 6/1), consists of silt- to clay-size particles, and is $5-20 \mathrm{~cm}$ thick on unit QTa. Clay content is noticeable, but not sticky. The upper 25-50 percent of the A horizon is vesicular. Variable amounts of carbonate have been leached from the upper part and deposited in the lower part of the $A$ horizon.

IThe term eolian A horizon is used because of the close association of this horizon with $B$ and $C$ horizons on units QTa and Q2. Although a soil horizon is normally formed in place, rather than deposited, the thinness of the A horizon, its association only with soils, and its post-depositional history make it resemble a soil horizon more than a depositional unit. Soil scientists who have seen this horizon have agreed that the deposit is a soil horizon even though by strict definition it might be termed loess. 
Desert pavements on unit QTa are very dense, even on very low slopes. Sorting is poor to moderate. Residual cobbles and boulders project above the pavement surface. Varnish is a blackish-brown to black shiny coating. Where QTa slopes merge with, rather than abut, Q2 slopes, pavements are continuous from unit QTa to unit Q2. Exposures of unit QTa are poor because caliche restricts dissection. The few outcrops and float indicate that unit QTa contains mostly cobbles and boulders and lacks bedding. Boulders from 0.5 to $1 \mathrm{~m}$ are found 15-20 $\mathrm{km}$ from their source. Boulders from 2 to $10 \mathrm{~m}$ in diameter are common near the base of unit QTa within $5 \mathrm{~km}$ of the ranges. Boulders of this size are not found in younger units except at a few places within $1 \mathrm{~km}$ or less of a range or as residual boulders from unit QTa. Lack of bedding and the abundant cobbles and boulders indicate that most of unit QTa was deposited as debris flows.

\section{Subunit QTc}

Colluvium, designated QTc, is mapped separately on steep slopes of Little Skull Mountain in the Lathrop Wells quadrangle. It is included with unit QTa at other locations. These deposits are formed from rockfalls and talus at the foot of steep outcrops of Tertiary volcanic rocks and grade downslope into unit QTa. Slightly dissected smooth slopes are underlain by several meters of Stage IV caliche. A and $B$ horizons are not present. The deposits consist of unsorted fine to coarse angular rubble. Younger rubble of Q2 and Q1 age are deposited on top of the colluvium.

\section{Subunit QTp}

The basal part of unit QTa in the Syncline Ridge area of Yucca Flat is a pediment gravel consisting only of quartzite and argillite fragments from the adjacent Eleana Range. The pediment gravel is about $5 \mathrm{~m}$ thick in outcrops in the western and southern parts of the valley between Syncline Ridge and the Eleana Range. In the eastern part of the valley, drill holes have penetrated as much as 22 $m$ of valley fill that is the lithologic and apparent time equivalent of the pediment gravel. Unit QTa above the pediment gravel and valley fill contains cobbles and boulders of volcanic rocks. The pediment gravel is poorly to well bedded and contains mostly fragments less than $0.2 \mathrm{~m}$ across. The maximum size is $0.7 \mathrm{~m}$ in contrast to numerous boulders from 1 to $10 \mathrm{~m}$ in diameter in unit QTa just above. The fragments are angular, platy prisms that have thicknesses of 20-50 percent of the maximum dimension. The pediment gravel is thoroughly cemented by layered caliche. Bedding and caliche layers dip into ridges of unit J (Mississippian) of the Eleana Formation. Some of the ridges are capped by unit QTa. These facts and a radiometric age of 128,000 years for the caliche suggest that the pediment gravel was deposited in shallow lows in the pediment cut on the Eleana Formation (fig. 3). Erosion after QTa was deposited carved valleys where the pediment gravel was very thin or absent. The caliche was deposited when the dissection reached the pediment gravel. Pediment gravels or their depositional equivalents have not been seen elsewhere on pediments beneath unit QTa.

\section{Regional Unconformity}

Unit QTa is separated from unit Q2 by a regional unconformity. After unit QTa was deposited, part of the unit was eroded to a plane, a soil was formed and then unit QTa was dissected. In adjacent areas of California such as Death Valley and Fish Lake Valley, the same events separate units QTa and Q2. Like the characteristics that differentiate the two units, evidence for the unconformity is 


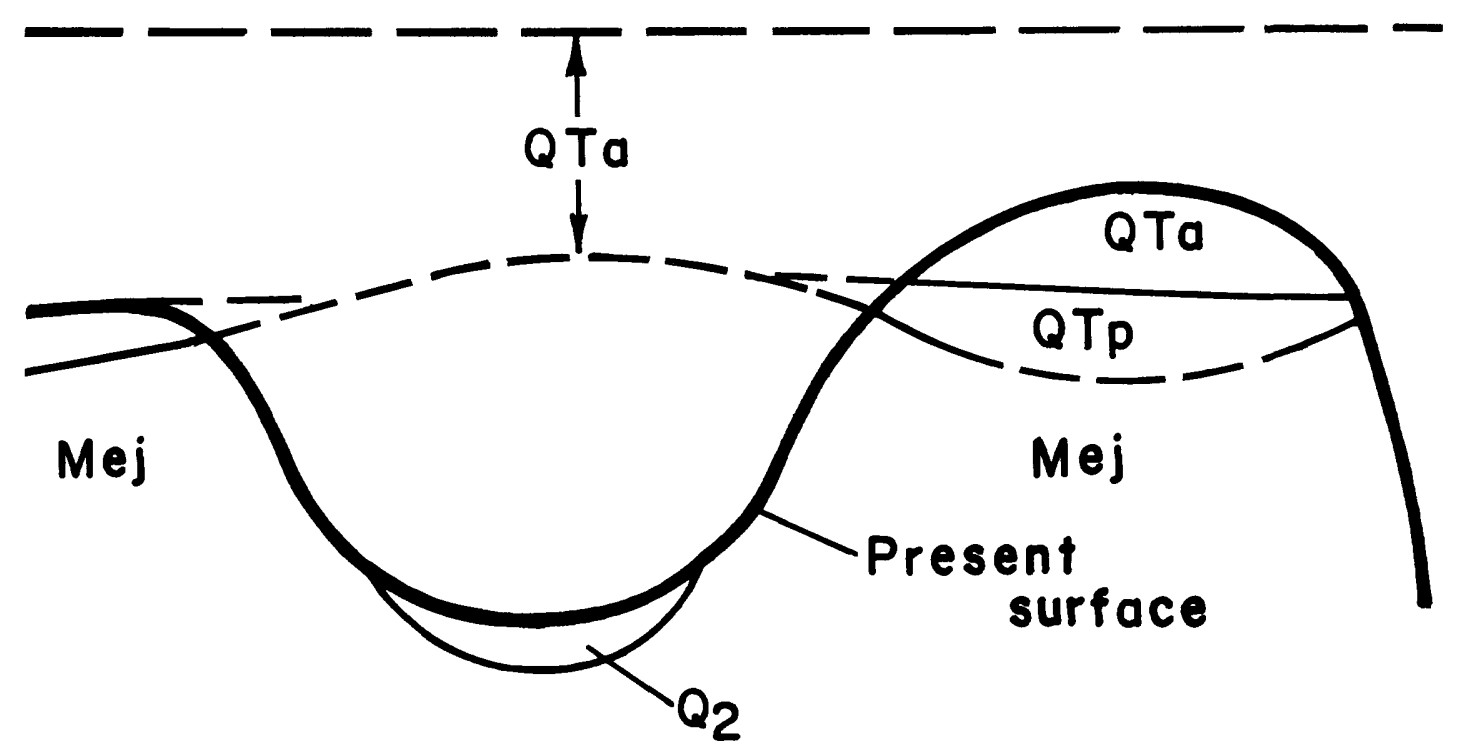

Figure 3.--Schematic cross section along contour showing deposition of pediment gravel (QTp) deposited in shallow lows on pediment beveled on unit $\mathrm{J}$ of Eleana Formation (Me) and overlain by unit QTa. 
exaggerated by local uplift or reduced by lack of uplift. The presence of this unconformity between the same units over a large area indicates that it is climatic in origin.

\section{Quaternary(?) or Tertiary(?) Deposits of Southern Crater Flat}

Lakebeds, well-bedded gravels, and spring deposits of uncertain age crop out on both sides of the hills forming the southern boundary of Crater Flat. Their location indicates that they may overlie unit QTa, indicating a Quaternary age, but contacts with QTa are not exposed. Pavements, soil horizons and terraces of Q2 age overlie these deposits, but contacts with $Q 2$ deposits are uncertain because of poor exposures. These deposits are described here as subunits of the Crater Flat unit (QTf), but their age may range from Tertiary to Holocene.

\section{Subunit QTfI}

Lakebeds (QTfl) crop out along the southern end of the main wash draining Crater Flat, along a major tributary of this wash draining from the west, and in separated small areas on the south side of the hills forming the southern boundary of Crater Flat. The lakebeds are white to buff, laminated to thick-bedded, poorly indurated, tuffaceous, sandy marls, siltstones, and diatomites. Fluvial fan deposits may be interbedded with the lakebeds at the northern and western outcrop limits, but poor exposures make this relationship uncertain. Outcrops are too small to determine most characteristics. The argillic B horizon and the eolian A horizon of unit Q2c are developed on the lakebeds, but pedogenic caliche has not been seen. Desert pavement is continuous from Q2C deposits onto the lakebeds. The soil profile and desert pavement indicate the minimum age of the lakebeds may be the same as Q2c deposits. Bedding characteristics and diatomaceous beds indicate a lacustrine origin. The diatoms in three samples indicate "....alkaline, at times slightly saline, shallow water. Many of the species (in the three samples) are found in alkaline, somewhat saline spring systems, but they are not restricted to this environment" (J. P. Bradbury, written commun., 1979). Northern outcrops appear to have more sand while diatomaceous beds occur only in the southern outcrops; but this distribution may be an effect of limited outcrops. These lakebeds may be equivalent to the Tertiary lakebeds in the Amargosa Desert mapped in the southern half of the Lathrop Wells Quadrangle. The higher altitude $(30-110 \mathrm{~m})$, the lack of limestone beds in the lakebeds of Crater Flat, and presence of diatomaceous beds make this correlation uncertain.

\section{Subunit QTfg}

Thin-bedded gravels with well-developed bedding planes (QTfg) crop out along a major tributary draining east into the main wash that drains Crater Flat. Beds vary from sands with less than 25 percent pebbles and small cobbles to gravels with predominantly pebbles and small cobbles in a matrix of sand. The pebbles and cobbles include both Paleozoic and volcanic rock fragments. Caliche thoroughly cements the gravels. The caliche appears to have been deposited by lateral migration of water away from or into the wash exposing the gravels. The gravels may be interbedded with the lakebeds, but dips suggest that they were deposited along a wash in about the same location as the present east-flowing wash. The gravels crop out lower than the Q2 surface in Crater Flat. 


\section{Subunit QTfs}

Spring deposits (QTfs), ranging from pale brown, vuggy tufa to white, relatively dense, siliceous caliche with scattered large pores, form mounds along the tributary where subunit Qfg crops out, along the major wash draining Crater Flat, and at an outcrop of subunit $Q \mathrm{fl}$ south of the hills forming the southern boundary of Crater Flat. The mounds range from 5 to $20 \mathrm{~m}$ in diameter. They are $0.5-1 \mathrm{~m}$ above the adjacent Q2 surface in the northern part of the outcrop area and 1-2 $\mathrm{m}$ above the Q2 surface in the southern part. Desert pavement is continuous from the mounds to the adjacent Q2 surface in northern outcrops, but southern mounds do not have pavement. The spring deposits appear to be interbedded with the gravels in northern outcrops and appear to lie on the lakebeds in both the northern and southern areas. The physical relationships of the spring deposits to the other deposits may be the result of juxtaposition and depositional mechanics rather than of stratigraphic position.

\section{Quaternary Deposits}

\section{Unit Q2}

Unit Q2 contains five subunits: Q2c, Q2b, and Q2a, fluvial fan deposits and debris flows; Q2e, eolian sand sheets and dunes; and Q2s, fluvial sand sheets. Correlation characteristics of these subunits are similar, particularly the soils and desert pavement.

The eolian A horizon, found on all Q2 surfaces, might be termed a sixth subunit because it originally was a loess deposit. Two soil scientists (John Hawley and F.F. Peterson, oral commun., 1979) more familiar with soils than the authors include this eolian deposit with the soil horizons. The eolian origin is confirmed by several facts. The A horizon is the same in appearance and is found on all Q2 subunits and unit QTa at different altitudes. The mineralogy, clay content, and carbonate content are approximately the same regardless of location or of the composition of the underlying material. It consists only of silt- to clay-sized particles except where the horizon has been disturbed by soil creep. Carbonate has been leached in the upper part and deposited in the lower part of the A horizon. Uranium and thorium isotope ratios indicate an eolian origin (J. N. Rosholt, oral commun., 1980). Finally, the $A$ horizon overlies different $B$ horizons or $\mathrm{C}$ or $\mathrm{K}$ horizons where $\mathrm{B}$ horizons have been stripped. It is clear that the $\mathrm{A}$ horizon associated with $\mathrm{Q} 2$ and QTa deposits is much younger than the $\mathrm{B}, \mathrm{C}$, or $\mathrm{K}$, horizons and that the deposits which the $A$ horizon overlies are not the parent material for the A horizon. Because of the close association with the Q2 soils and the fact that it cannot be mapped separately at mapping scales of 1:24,000 or smaller, the eolian A horizon is included with the other Q2 soil horizons.

\section{Subunit Q2c}

Subunit Q2c is the oldest subunit of unit Q2. Fluvial deposits and debris flows of three different ages may be included, but the only apparent differences are in the soil horizons. Q2c was deposited at the same time as subunits Q2e and Q2s.

Subunit Q2c occurs on the middle to upper parts of valley slopes, as terraces in some larger drainages of the ranges, and on parts of valley slopes of intrarange valleys. Cuttings in a drill hole indicate a maximum thickness of $65 \mathrm{~m}$, but the maximum may be as much as $100 \mathrm{~m}$. 
Macrotopography is flat. Overbank flood deposits along some major drainages during Q2 time have resulted in a slightly convex surface parallel to the drainage. The convex surface is from 20 to $50 \mathrm{~m}$ wide and 0.5 to $1 \mathrm{~m}$ above the adjacent flat surface. Microrelief is less than $0.2 \mathrm{~m}$ except near the ranges and where less than $2 \mathrm{~m}$ of Q2c overlie unit QTa. Boulders larger than $0.5 \mathrm{~m}$ may protrude above the flat surface at these locations.

Drainage patterns are dendritic to parallel dendritic and have developed upslope. Holocene (QI) washes have destroyed most of the evidence of Q2c drainage. The heads of some Q2c washes are gently concave depressions less than I $\mathrm{m}$ deep and 10-20 $\mathrm{m}$ wide. Denny (1965) postulated that alluvial fans dissected by abandoned washes were transformed into pavemented smooth surfaces by creep. The gentle depressions at the head of Q2c washes have about the same soil and pavement as the surrounding flat areas, indicating that the surface was probably smoothed prior to soil and pavement formation.

Near the ranges, subunit Q2c is higher in altitude than all Q2 subunits except Q2a and Q2e. Q2c is lower than unit QTa near the ranges, but the subunit usually covers unit QTa within $1-5 \mathrm{~km}$ of the ranges. In tectonically inactive areas, subunit Q2c may be lower than unit QTa at distances of $10-15 \mathrm{~km}$ from the ranges. Q2c is covered by unit Q1 at distances of $5-15 \mathrm{~km}$ from the ranges. Below large intrarange basins that do not have Q2 drainage entrenchment, subunit Q2c is covered on the upper part of Q2c fans by irregular sheets and patches of Q1 that are less than I $\mathrm{m}$ thick.

At least three different soils are present on subunit Q2c, but other correlation characteristics do not vary greatly. Irregular stripping of B horizons near the ranges and less than $2 \mathrm{~m}$ of deposition at lower altitudes indicate that erosion and deposition between soil development periods were minor. The best developed, and presumably the oldest, soils are at the highest altitudes and the least developed, and presumably the youngest, soils are usually at the lowest altitudes on individual fans. The least developed soils can be found on the highest part of some fans. These soils may represent three different periods of soil development, but they may also represent continuous soil development with stripping at the top of fans and deposition at the bottom accounting for distribution of the soils.

The oldest soil has a Stage IV $K$ horizon that is $1-2 \mathrm{~m}$ thick. The $\mathrm{K}$ horizon development has not proceeded far enough to develop the laminated upper part typical of unit QTa. The $K$ horizon engulfs part of an argillic $B$ horizon that is 0.3-0.7 $\mathrm{m}$ thick. The $B$ horizon is between moderate reddish brown $(10 R$ 4/6) and dark reddish brown (IOR 3/4). The $B$ horizon is silicified to the extent that it forms thick prismatic plates that require hammering to break them. The intermediate age soil has a Stage III to IV $\mathrm{K}$ horizon about I $\mathrm{m}$ thick overlain by an argillic $B$ horizon about $0.5 \mathrm{~m}$ thick. The $B$ horizon varies from moderate reddish brown ( $10 R$ 4/6 to moderate brown (5YR 4/6) or light brown (5YR 5/6). The amount of clay ranges from noticeable to enough to be sticky. The youngest soil on subunit Q2c has a Stage II to Stage III $K$ horizon from 0.5 to $1 \mathrm{~m}$ thick overlain by a cambic $B$ horizon less than $0.5 \mathrm{~m}$ thick. The $\mathrm{B}$ horizon is light brown (5YR $5 / 6)$ and has a clay content that ranges from clay skins on sand size fragments to noticeable when wetted. The three soils are not always present everywhere on Q2c surfaces. These soils have not been mapped separately because of the lack of other distinctive characteristics and the irregular areal distribution of the three soils. 
Desert pavements on subunit Q2c are densely packed. Except near bedrock outcrops or where depths to bedrock or unit QTa are less than I m, pavements are moderately to well sorted and rarely contain fragments greater than $0.2 \mathrm{~m}$ in diameter. Sorting is poor where the subunit is less than $1 \mathrm{~m}$ thick and overlies unit QTa. Varnish is a blackish brown, dull to shiny coating that completely covers the exposed parts of the fragments. The only difference in subunit Q2c pavements is the presence of patterned ground in some areas. The patterned ground forms arcs or lineations on irregular patches of treads and risers. Treads and risers range from 5 to $25 \mathrm{~m}$ in width with risers from 0.2 to $1 \mathrm{~m}$ high and treads nearly horizontal. Treads are bare of vegetation and risers have closely spaced vegetation. The patterns are probably caused by soil creep (Morrison and Hoover, written commun, 1980) and are related to the vesicular A horizon rather than the depositional unit beneath it. Patterned ground is also present on $Q 2$ soils lying on unit QTa in a few areas. Patterned ground is restricted almost totally to subunit Q2c because the long slopes needed to form patterned ground are available mostly on this subunit.

Subunit Q2c is yellowish to grayish brown. Lithology indicates that fluvial deposits are equal to or greater than debris flows. The fluvial deposits have a smaller median fragment size than the debris flow deposits. Sand-, silt-, and claysized material is variable in the fluvial deposits, but more abundant than in the debris flows. Sand is present as continuous beds less than $1 \mathrm{~m}$ thick. Bedding is well defined in contrast to the lack of bedding in unit QTa. Clay and silica skins on larger fragments are not present except on a few fragments within $1-2 \mathrm{~m}$ of the surface.

\section{Subunit Q2e}

Subunit Q2e is present as sand dunes and eolian sand sheets in the Amargosa Desert and on the sides of the ranges bordering this area to the north and northeast. The subunit has not been recognized in areas north of and east of Jackass Flats and Rock Valley. The distribution of these eolian deposits indicates that prevailing winds from the south or southwest deposited sand at the first topographic highs north and east of the Amargosa Desert. Alluvium intercalated with the dunes indicates that $Q 2 e$ lies within subunit Q2c. In a few places remnants of Q2c surfaces form terraces along drainages in dunes. Sand sheets are only a few meters thick, but dunes may be 50-60 m thick normal to bedding.

The macrotopography, microrelief, and drainage patterns in subunit $Q 2 e$ are similar to those of subunit Q2c. Drainages on dunes are spaced 100-500 m apart and have fewer tributaries than on subunit Q2c. Dissection by $Q 1$ drainages are $15-40 \mathrm{~m}$ deep. Q2 terrace remnants in some drainages indicate that $Q 1$ drainages follow older drainages in the dunes.

Dunes of subunit Q2e are as much as $100 \mathrm{~m}$ above adjacent Q2c surfaces and are higher in altitude than all younger units except Qle. In a few places wedges of subunit Q2c lie on top of these dunes. In other locations sand sheets of Q2e lie on top of $Q 2 c$.

Soils on subunit Q2e are similar to those on subunit Q2c. On dunes the B horizon has been stripped, either by sheet wash or soil creep. The $K$ horizon is Stage III to Stage IV and is from 1 to $2 \mathrm{~m}$ thick. The A horizon is similar to that of subunit Q2c. The sand sheets at lower elevations usually have a $B$ horizon that is moderate reddish brown (IOR 4/6) to moderate red $(5 R 4 / 6)$ and is $1-2 \mathrm{~m}$ thick. 
Clay content of the B horizon in the sand sheets is less than that of subunit Q2c and varies from clay skins on sand particles to noticeable. The darker colors, greater thickness, and lesser clay content of the B horizon are probably caused by differences in permeability between the sand and the poorly sorted alluvium of subunit Q2c.

Desert pavements on subunit Q2e are similar to those of subunit Q2c, but range from loosely to densely packed. The packing appears to depend on slope and on how recently rock fragments have been supplied from bedrock ridges above the dunes or sand sheets. Dissection of dunes has cut off the supply of rock fragments from higher bedrock ridges. This dissection clearly reveals that the single layer of fragments forming densely packed pavements has migrated down relatively steep (5-15 percent) slopes for distances of at least $1 \mathrm{~km}$ from the bedrock ridges above the dunes.

Subunit Q2e is entirely an eolian deposit. The subunit is composed of very fine to fine-grained sand with only trace amounts of clay and silt-sized particles. The only fragments larger than sand are single fragments up to $5 \mathrm{~mm}$ in diameter scattered along some bedding planes. Crossbedding is present in some beds, but most beds are uniform and range from a few centimeters to one meter in thickness. The color of large exposures ranges from light gray (N7) to light brownish gray (5YR 6/1).

Ash of the Bishop Tuff has been found in several places at or near the base of subunit Q2e. The tuff is present as lenses of reworked vitric ash. These lenses are present only in pre-Q2 drainages within or at the edge of ranges bordering the Amargosa Desert.

\section{Subunit Q2s}

Subunit Q2s is found overlying subunit Q2c in the lower reaches of major drainages and along larger tributaries downslope from Q2e dunes. The subunit consists of sheets less than $10 \mathrm{~m}$ thick that were derived from Q2e. The sheets are undissected except by the larger QI washes.

The correlation characteristics and lithology of subunit Q2s are much like subunit $Q 2 e$ with two exceptions. The $B$ horizon of subunit $Q 2$ s is intact in many places. It is a moderate red (5R 5/4-5R 4/6) and contains noticeable clay coating the sand grains. The subunit contains 5-10 percent subrounded to rounded pebbles and cobbles up to $20 \mathrm{~cm}$ in diameter.

The stratigraphic boundaries of subunit Q2s are inferred. The subunit may be younger than $Q 2 e$ or it may be coeval with the upper part of subunit Q2e. It overlies subunit $Q 2 c$, but has not been found on subunit $Q 2 b$.

The thickness and distribution of subunit Q2e and the distribution of subunit Q2s indicates that Q2e choked drainages in the ranges and that Q2c was deposited when these drainages were flushed out. Q2s was also deposited from later dissection of Q2e.

\section{Subunit Q2b}

Subunit Q2b is mappable only as strath terraces in subunit Q2c, unit QTa and in the older rocks of the ranges. The terraces are found as isolated remnants, and 
rarely as paired terrace remnants, along entrenched drainages throughout the NTS region. Below entrenched drainages the subunit cannot be distinguished from subunit Q2c. The terraces are termed strath terraces because recognizable fill has not been seen. Some of these terraces consist only of a change in slope 5-10 $m$ wide with varnished rocks scattered along the changes in slope.

Subunit Q2b differs from Q2c only in its topographic position and in its soil horizons. The $\mathrm{Q} 2 \mathrm{~b}$ terraces range from 2 to $25 \mathrm{~m}$ below $\mathrm{Q} 2 \mathrm{c}$ surfaces in most drainages to a maximum of $30 \mathrm{~m}$ in Fortymile Wash. The subunit ranges from 2 to $10 \mathrm{~m}$ above present wash (Q/a) bottoms.

The A horizon of subunit Q2b is similar to that of Q2c. The B horizon is cambic with clay skins on sand particles and is light brown (5YR 6/4-5YR 5/6) in color. The $C$ horizon is Stage $I$ and consists of $1-3 \mathrm{~mm}$ coatings of caliche on the bottom half of pebbles in a single layer or thin bed. The A horizon and also desert pavement are often continuous from Q2c surfaces down to Q2b terraces where terraces are less than $3 \mathrm{~m}$ lower than the Q2c surface. The pavement appears to have the same packing and fragment sizes as on subunit Q2c.

\section{Subunit Q2a}

Subunit Q2a has been found in only three locations: in Yucca Flat between Syncline Ridge and the Eleana Range, in Jackass Flat just west of Topopah Wash, and in the southern part of Crater Flat. The subunit is present on both sides of single drainages in Yucca and Jackass Flats. Subunit Q2a probably has more than one source in Crater Flat, but only single drainages appear to be the source for any single area within Crater Flat. The subunit extends less than $5 \mathrm{~km}$ from the ranges in Yucca and Jackass Flats; in Crater Flat the distance may be $10-15 \mathrm{~km}$. The maximum thickness is approximately $3 \mathrm{~m}$.

Topography and desert pavement distinguish subunit Q2a from other Q2 subunits. The macrotopography is slightly convex and microrelief is moderate in contrast to the flat surfaces of other Q2 subunits. The only drainages in subunit Q2a are entrenchment of the major drainages of basins in the ranges and headward extension of a few tributaries that first developed in subunit Q2c. Soil horizons on subunit Q2a are similar to those of subunit Q2b: a Stage I C horizon, a cambic B horizon, and the vesicular $A$ horizon that are all about the same as for subunit Q2b.

Desert pavement on subunit Q2a is loosely packed and has poor sorting in contrast to the moderate to dense packing and good sorting of other Q2 subunits. In Yucca Flat and in Jackass Flats, single boulders from 0.5 to $1 \mathrm{~m}$ in diameter are irregularly scattered 10-25 m apart on the pavement. Varnish is a dark-brown, dull to shiny film.

Although poorly exposed, subunit Q2a appears to be a single debris flow derived from single drainage basins in the ranges. These drainage basins have two characteristics in common: (1) They are larger than adjacent basins in the ranges, and (2) they lack Q2b terraces. The larger size, lack of Q2b terraces and the position of Q2a on top of Q2c, indicate that these basins had different geomorphic characteristics from smaller adjacent basins. This inferred different geomorphology and the apparent deposition of Q2a as a single debris flow indicates that $Q 2 a$ may have been deposited during a single, intensely wet season and perhaps even from a single storm. 
The lithology of subunit $Q 2 a$ is similar to that of debris flows in other subunits, but fragment size distribution appears to differ. Sand-, silt-, and claysizes comprise one-third to two-thirds of the fragments in Q2a whereas in debris flows of other subunits these sizes rarely make up more than a third of the fragments. Silt and clay sizes in Q2a are a significant component whereas in debris flows of other Q2 subunits these sizes make up less than 5 percent of the deposits. These differences in fragment sizes supplement the evidence for differences between $Q 2 a$ and other $Q 2$ basins.

\section{Regional Unconformity}

Unit $Q 2$ is separated from the younger unit $Q 1$ by a regional unconformity. The A horizon and the overlying pavement, common to all $Q 2$ subunits, is the boundary for the regional unconformity. Following deposition of the $A$ horizon and pavement development, erosion dissected unit Q2 and deepened many of the larger drainages. Unit $Q 1$ was deposited in these newly entrenched drainages and on the lower parts of $Q 2$ alluvial fans below the entrenched drainages. Some drainages were not entrenched immediately and the oldest subunit of QI was deposited as thin sheets on unit Q2.

\section{Unit QI}

Unit QI contains five subunits: Qlc, Qlb, and Qla, predominantly fluvial deposits with variable, small amounts of debris flows; Qle, eolian deposits; and Qls, fluvial sand sheets. In comparison to units QTa and Q2, unit Q1 has been modified very little since deposition. Soil development is incipient, desert pavements are not present, and only the oldest surfaces have been smoothed by soil creep and sheet wash. Unit QI is predominantly fluvial. Debris flows may form a major part of the deposits in small areas, but probably form less than 20 percent of all QI deposits. Unit QI is found along drainages eroded into the ranges and older alluvial units; as thin sheets overlying unit QTa and subunit Q2c; and as wedges of alluvium that thicken down slopes at distances of $5 \mathrm{~km}$ or more from the ranges. The maximum thickness of unit $Q I$ identified in a drill hole is approximately $35 \mathrm{~m}$, but in the lowest part of some basins, it may be $100 \mathrm{~m}$ thick.

\section{Subunit Qlc}

Subunit Qlc is composed almost entirely of fluvial deposits. Debris flows are rarely seen and probably form less than 10 percent of the subunit in small areas. The subunit occurs as thin sheets in intrarange valleys and on subunit Q2c downstream from the mouths of some larger drainages; and as wedges that thicken downslope at distances of $5 \mathrm{~km}$ or more from the ranges. Subunit Qlc also forms alluvial fans on bedrock slopes greater than 10 percent and terrace remnants in larger drainages.

The macrotopography is flat to slightly convex. Microrelief ranges from less than 0.2 to less than $0.5 \mathrm{~m}$. Boulder trains and patches are present at scattered locations but microrelief of these areas is less than $0.5 \mathrm{~m}$. At a few places isolated boulders as much as $1 \mathrm{~m}$ in diameter are scattered across surfaces where the subunit forms sheets less than $2 \mathrm{~m}$ thick on top of subunit Q2c.

Drainage development in Q/c has been mostly obliterated by postdepositional smoothing and later drainage development. Distribution of subunit QIc indicates that drainage in the ranges and immediately below the ranges consisted mainly of deepening of $Q 2$ channels. At distances of $5 \mathrm{~km}$ or more below the ranges Q/c 
drainages probably developed downslope by diverging into numerous braided or anastamosing channels. Drainages in subunit Qlc are flat bottomed with very steep to vertical banks and are usually less than $5 \mathrm{~m}$ deep.

Subunit Qlc is present at both higher and lower altitudes than unit Q2, and in most areas is lower than unit QTa. Along larger drainages and in the upper $1 \mathrm{~km}$ or less of smaller drainages the subunit is 10-40 m below Q2c surfaces and 2-10 m below Q2b surfaces. Between larger drainages Qlc was deposited as thin sheets on subunit Q2c.

Soils on the subunit are incipiently developed. The $C$ horizon consists only of Stage I caliche films on the bottoms of pebbles in a single layer or bed. The caliche is $0.5 \mathrm{~m}$ or less beneath the surface. The $A$ horizon is detectable only where the upper part of the subunit is sandy. At such locations the A horizon consists of a $2-10 \mathrm{~cm}$ zone that has been leached of carbonate. Color changes in the $A$ horizon are not visible.

Pavements have not been developed on subunit Qlc. In some areas where fragments are well sorted and less than $0.1 \mathrm{~m}$ in diameter, the flattening of topography by soil creep and sheet wash have produced a rude pseudopavemant. Desert varnish on subunit Qlc in the NTS region consists of scattered, faint brown, dull spots of film on selected lithologies. This varnish may be relict from older deposits, but the uniform and lightly varnished appearance of the spots suggests that the varnish was developed in place.

In the NTS region much of subunit Qlc is predominantly volcanic rock fragments derived from bedrock. Contributions from units QTa and Q2 are important only in small areas. Maximum fragment sizes are less than $0.5 \mathrm{~m}$ except in deposits from large drainages where diameters may reach $1 \mathrm{~m}$. Fragments larger than $0.3 \mathrm{~m}$ are probably less than 5 percent of Q/c deposits. Beds of sand or mostly sand form 25-50 percent of the subunit in some areas. Clay, either as beds or as interstitial clay, is almost totally absent. The color of Qlc outcrops is between light brownish gray (5YR 6/I) and light gray (N7).

\section{Subunit Qls}

Subunit Q/s forms sheets overlying subunit Qlc and older units in the Amargosa Desert and in valleys around its periphery. Its absence on subunit QIb indicates that it was derived from older deposits of sand before subunit Qlb was deposited. In the Lathrop Wells quadrangle the subunit overlies unit QTa. The maximum thickness seen is $5 \mathrm{~m}$, but in the Amargosa Desert the subunit may be 10-20 $\mathrm{m}$ thick down slope from major drainages.

Macrotopography of subunit QIs is flat. Microrelief is less than $0.2 \mathrm{~m}$. Only major drainages originating up slope from Qls are present because of high infiltration of runoff. Qls covers terraces of Qlc in major drainages and the upper reaches of smaller drainages in unit QTa. Maximum thickness of QIs on these terraces is $3 \mathrm{~m}$.

Soils in subunit Q/s consist of leaching of calcium carbonate from 2 to $5 \mathrm{~cm}$ below the surface and deposition of questionable pedogenic caliche in the upper $0.5 \mathrm{~m}$ as films on particles in a layer a few centimeters thick. No color change is apparent in the leached zone. Normal desert pavement is not present on QIs. A deflation pavement is present in most areas. The pavement is formed by removal of sand and smaller particles by wind leaving pebbles and cobbles to form a 
pavement. The pavement has a packing density from 20 to slightly more than 50 percent. The sand immediately beneath the deflation pavement contains less than 10 percent pebbles and cobbles. The pavements are present in large areas with slopes less than 2 percent.

Subunit Qls contains pebbles and cobbles as much as $15 \mathrm{~cm}$ in diameter in a matrix of sand. The larger fragments range from less than I percent to a maximum of 1.0 percent of the subunit. Their presence indicates the fluvial origin of QIs. Sand from Qle, and probably Q2e and Q2s, that choked the mouths of drainages in the ranges was eroded and spread across the lower slopes of the valleys. The larger fragments were probably derived from both the ranges and from older fluvial deposits.

\section{Subunit Qle}

Subunit Qle consists of dunes and remnants of sand sheets scattered throughout the Amargosa Desert and its peripheral ranges. The subunit has not been identified north and east of Jackass Flats or in Mercury Valley. The subunit represents two depositional periods, one between subunits QIC and QIb and one after subunit Qlb that extends to the present. Deposits of the two periods are mapped as a single subunit because of their small areal extent. The two periods are distinguished from each other by differences in their soil profiles and their relationship to QIb.

Big Dune in the Amargosa Desert is the best example of subunit Qle and probably represents both periods of deposition. The subunit is more than $75 \mathrm{~m}$ thick at Big Dune, but the thickness is probably less than $20 \mathrm{~m}$ elsewhere. Deposits of the youngest period are best seen around the young basalt cone northwest of Lathrop Wells where active dunes of the younger period overlie remnants of dunes of the older period.

Sand sheets of subunit Qle are poorly exposed and are often difficult to separate from subunit QIs. The maximum thickness seen is less than $1 \mathrm{~m}$, but the thickness may be much greater in the Amargosa Desert.

Dunes have an irregular macrotopography with microrelief ranging from 0.2 $\mathrm{m}$ to greater than $0.5 \mathrm{~m}$. Sand sheets have a flat macrotopography and a microrelief less than $0.2 \mathrm{~m}$. On slopes of less than 5 percent only major drainages are present because of high infiltration of runoff. On steeper slopes smaller drainages are present, but they are usually shallower and more rounded than those in adjacent coarser deposits. Dunes are scattered at all altitudes. They range from isolated dunes on bedrock well above other Quaternary deposits to Big Dune and adjacent sand sheets in the bottom of a valley. Older deposits of sand sheets overlie subunit QIC or older units whereas younger deposits of the subunit form irregular sheets on dunes and subunit Qlb at lower altitudes. The sand sheets of Qle are generally at higher altitudes than subunit Qls.

Soils on subunit Qle are poorly developed. The only visible evidence of a soil is the leaching of carbonate in the upper $5-10 \mathrm{~cm}$ of the sand and a questionable pedogenic caliche in the upper $0.5 \mathrm{~m}$. No color change is apparent in the leached zone. The questionable pedogenic caliche is Stage I to II, deposited preferentially along a bedding plane or within one bed. The younger deposits of subunit Qle lack carbonate leaching and caliche. Desert pavement is not present on the subunit. Pavements on sand are actually deflation pavements formed on subunit Qls. 
The depositional environment of the subunit is eolian. Particles are sandand silt-sized. Single layers of pebbles as much as $5 \mathrm{~mm}$ in diameter are found at bedding planes.

\section{Subunit QIb}

Subunit Qlb forms low terraces along nearly all drainages originating in bedrock and thin sheets below these drainages that widen downslope. The thickness of the unit is usually less than $3 \mathrm{~m}$, but it may be $5-10 \mathrm{~m}$ at the base of steep slopes.

Topography and, in larger areas, drainage in subunit Qlb readily distinguish Qlb from Qlc. Macrotopography is irregular to highly dissected. Microrelief on steeper slopes is greater than $0.5 \mathrm{~m}$ and on gentle slopes is between 0.2 and 0.5 m. Typically, the subunit forms bars and swales. Boulder patches and trains commonly form the bars with little material less than $1 \mathrm{~cm}$ in diameter. Drainage is anastamosing or braided with patterns widening downslope below the bankfull point of incised feeder drainages. Drainages are $U$-shaped to rectangular in cross section. Depths of drainages are usually less than $2 \mathrm{~m}$, but they may be as much as $5 \mathrm{~m}$ at the foot of steep slopes.

Subunit Qlb forms terraces ranging from 0.5 to $2 \mathrm{~m}$ above the present washes. Below the bankfull point of drainages, the subunit often forms a fan as much as $3 \mathrm{~m}$ above Qlc deposits.

Soils and desert pavement are not present on the subunit. A thin Stage I film of caliche has been seen on single layers of pebbles along stream banks, but this caliche may not be pedogenic.

Depositional environments are both fluvial and debris flows. Debris flows may approach the amount of fluvial deposits in volume but fluvial deposits exceed the debris flows in areal extent because the debris flows are confined to the steeper parts of the drainages. Fragments as much as $2 \mathrm{~m}$ in diameter are present at and above the foot of steep slopes but on lower slopes maximum diameters are less than $1 \mathrm{~m}$. Sand or smaller size particles are present as lenses in the subunit, but do not form the continuous beds found in subunit Qlc.

\section{Subunit Qla}

Subunit Qla forms the deposits in the bottoms of modern washes. In most areas these deposits are not wide enough to map separately from subunit Qlb. Maximum thickness is probably less than $5 \mathrm{~m}$.

Macrotopography cannot be determined because outcrop areas are too small. Microrelief ranges from less than $0.2 \mathrm{~m}$ to less than $0.5 \mathrm{~m}$. In areas where the bankfull point is reached within I or $2 \mathrm{~km}$ of large, very steep drainages, the microrelief may be greater than $0.5 \mathrm{~m}$. Drainages are braided with braiding usually increasing downstream. Depths of drainages within the deposits are less than $1 \mathrm{~m}$ in the NTS region. The subunit is less than $2 \mathrm{~m}$ below subunit Qlb, but at the foot of steep slopes the subunit may be as much as $5 \mathrm{~m}$ below QIb. Below the bankfull point, drainages diverge and are braided with depths of less than $0.5 \mathrm{~m}$. Soils and desert pavement are not present in the NTS region. 
The depositional environment of subunit Qla is fluvial in the NTS. Small debris flows may be present, but have not been recognized. Fragment sizes are mostly less than $0.8 \mathrm{~m}$. Larger fragments are probably residual and derived from older Quaternary deposits.

\section{AGE}

The absolute ages of the Quaternary deposits in the NTS region are uncertain. The few age dates available, scattered paleontological data, and correlations with other areas are consistent, but the limits of even the major units, Qta, Q2 and Q1, are only approximate. Studies of Quaternary stratigraphy in the western U.S. indicate that major glacial or interglacial periods were between 25,000 and 300,000 years long (Birkeland, Crandell, and Richmond, 1971). Deposition of units QTa and Q2 and the regional unconformities developed between these two units and between units Q2 and Q1 are believed to be climatic periods of equivalent length.

Ash beds in the middle part of the lakebeds beneath unit QTa have been dated at 2.95 m.y. (C. W. Naeser, written commun., 1980) and 3.1 m.y., (R. L. Hay, written commun., 1979). The Bishop ash, 730,000 years old, has been found at several locations in the basal part of subunit Q2e near the base of subunit Q2c. The outcrops of Bishop ash are just above Paleozoic sedimentary rocks and Tertiary volcanic rocks. Thus, subunit Q2c could include deposits much older than the Bishop ash. The uniformity of QTa indicates that it is a single depositional period. The relatively constant topographic relationships of $Q T a$ and $Q 2 c$, their consistent correlation characteristics and the lack of any depositional unit between them in an area of more than $5000 \mathrm{~km}^{2}$ indicates that QTa and Q2c are two consecutive depositional periods. Finally, development of $B$ horizons, silica, and caliche in QTa and Q2c also indicate consecutive depositional periods. The evidence indicates the deposition of $Q T a$, development of the regional unconformity and deposition of Q2c are three consecutive climatic periods. An age determination of soil (J. N. Rosholt, written commun., 1979) on the pediment gravel at the base of unit QTa indicates that it is more than 900,000 years old. Basalt cones in Crater Flat ( 1.1 m.y.) may be partly beneath a surface cut on QTa. The evidence indicates that unit QTa may be between 0.9 and 1.1 m.y. old.

Development of the regional unconformity between QTa and Q2 includes erosion of 25-100 m of QTa to a planar surface, development of a soil with an argillic B horizon and finally dissection of QTa prior to deposition of Q2c. Continuous erosion during this period indicates either a single climatic period or, more probably, two climatic periods separated by a climatic change that caused formation of the argillic B horizon on unit QTa. Geomorphic stability during the climatic change is indicated by planar surfaces and soil formation on QTa. It is also indicated by lack of deposition on QTa around the edges of valleys. The time period between units QTa and Q2 may have been as long as the period required for deposition of unit QTa.

Presence of the Bishop ash in the base of subunit Q2e near the base of subunit Q2c indicates that the maximum age of unit Q2 may be slightly more than 730,000 years old. Neither subunit Q2e nor the Bishop ash is present everywhere at the base of Q2c, and therefore, Q2c may be much older than 730,000 years. However, when the large area is considered, the consistent relationships of QTa and $Q 2 c$, the apparent uniformity of $Q 2 c$, and the lack of any evidence for an event between dissection of Qta and $Q 2 c$, indicate that deposition of $Q 2 c$ 
immediately followed the dissection of QTa. The maximum age of Q2c may be somewhat greater than 730,000 years, but it is probably not as great as that required for a climatic period.

Unconformities and soils are not present in subunit Q2e and indicate deposition of $Q 2 e$ in a relatively short period of time. Bedding planes do not indicate erosion even on steeply dipping beds of dunes deposited against bedrock ridges. Lenses of alluvium within subunit Q2e are only a few meters thick and pinch out downslope. These lenses probably represent a single intense storm or a few intense storms within a short time period. Subunit Q2e may have been deposited in a few tens of thousands of years.

Soils and caliche at the top of subunit Q2 have been dated at several locations by uranium-thorium disequilibrium methods. All of these dates, whether from single samples of caliche or from multiple samples of soil, have ages between 110,000 and 250,000 years (J. N. Rosholt and B. J. Szabo, oral commun., 1977-79). These age dates represent only the oldest soils and caliche of unit Q2. In the Syncline Ridge area of Yucca Flat, a nonpedogenic caliche was deposited in the pediment gravel (QTp) at the base of unit QTa on a narrow ridge of the Eleana Formation (Devonian and Mississippian). The caliche appears to have been deposited from seepage along a thrust fault in the Eleana Formation about $50 \mathrm{~m}$ higher and about $300 \mathrm{~m}$ west of the sample site. The relationships in this area indicate that the caliche was deposited during planation of the pediment gravel. After planation, the pediment gravel and the Eleana Formation were eroded to narrow ridges with valleys about $25 \mathrm{~m}$ deep. Finally, subunit $\mathrm{Q} 2 \mathrm{c}$ was deposited in the valleys. Undisturbed basal caliche that dips $12^{\circ}$ away from the adjacent valley has an age of $128,000 \pm 20,000$ years; laminated redeposited caliche near the surface that dips toward the valley has an age of 4,000 2,000 years. The older caliche dipping into the ridges indicates deposition before the valleys were formed; the laminar caliche dipping into the valleys indicates that this caliche was deposited after the valleys were formed. These ages indicate that subunit Q2c in this area was deposited less than 128,000 years ago and more than 4,000 years ago. The $B$ horizon of subunit Q2c is cambic, and pedogenic caliche is Stage II to III. Therefore, it seems probable that the parts of subunit Q2c with argillic B horizons and Stage III to IV caliche are older than 128,000 years and the parts with Cambic B horizons and Stage II to III caliche are younger than 128,000 years.

The origin of the eolian $A$ horizon and the lack of conformity of this horizon with the $B$ and $C$ horizons indicates a younger age for the $A$ horizon of unit $Q 2$ soils. On the basalt cone northwest of Lathrop Wells, caliche in a loess at the base of unit Qle was dated at 25,000 years (B. J. Szabo, written commun., 1978). The loess resembles the $A$ horizon in color, grain size, and thickness, but it is so impregnated with caliche that the correlation is only tentative. In Frenchman Flat age on the A horizon indicates that it is $40,000 \pm 30,000$ years old $(\mathrm{J} . \mathrm{N}$. Rosholt, oral commun., 1980). Although imprecise, this age may correspond to the dry period of the point E low stand of Searles Lake (Smith, 1979). It would appear that either the loess on the basalt cone is not the A horizon or, more likely, that the date on the loess represents caliche deposited at a later time than the loess.

Unit Q1 has been inferred to represent the Holocene. The poor soil development would tend to confirm this inference. The base of the Holocene has been placed at 10,000-12,000 years ago by various workers in the southwestern U.S. Studies of packrat middens suggest that the major change in vegetation took place about 8,000 years ago (Van Devender and Spaulding, 1979). In the NTS 
region numerous Pleistocene packrat middens are perched on steep to vertical bedrock slopes as much as $15 \mathrm{~m}$ above the present colluvial slopes. Holocene middens (less than 8,000 years old) are at or just above these slopes. This difference in location indicates that although a climatic change probably took place between 10,000 and 12,000 years ago, the vegetation change needed for erosion on steep slopes and deposition of unit QI did not begin until about 8,000 years ago.

Similarities of unit QI and the Holocene depositional units A-E of Haynes (1968) make tentative correlations to Tule Springs near Las Vegas possible. Subunit $Q$ Ic resembles Haynes' depositional units $A$ and $B$, but if deposition of $Q 1$ began about 8,000 years ago at NTS, then only unit $B$ corresponds to $Q I c$. The youngest age of unit $B$ is 7,000-8,000 years. The older part of subunit $Q / e$ and probably $Q$ /s correlate with depositional unit $C$ between 4,000 and 7,000 years ago. The Qle dunes represent the Altithermal interval and the incipient soil on QIe and QIs corresponds to the Altithermal soil of Malde and Schick (1964). The age of the soil is between 3,300 and 5,700 years B.P. (Haynes, 1968, p. 608). Subunit QIb correlates with depositional units $D$ and $E$. The age of these units ranges from 4,900 years ago to about 1840. In the NTS area subunit QIb is younger than the soil on subunit $Q$ Is. Therefore, $Q$ Ib may be no older than 3,300 years.

The arroyo-cutting period that began about 1840 has been noted at numerous locations in the western U.S. Subunit Qla corresponds to this arroyo-cutting period. The age of Qla was confirmed by tree-rings in a large juniper tree growing on a Q Ib terrace. The juniper is 120 years old. Large roots were killed 50 years ago by cutting of a Qla wash about $0.7 \mathrm{~m}$ deep.

In summary, the age of unit QTa is between 730,000 and 2.95 m.y. old. Geomorphic and geologic evidence indicate that QTa is probably between 0.9 and I.I m.y. Most of subunit Q2c was deposited less than 730,000 years ago. No evidence has been found to indicate that Q2c is substantially older than 730,000 years. The minimum age of Q2c is established by soils on Q2c between 110,000 and 250,000 years old, but deposition could have ended well before 200,000 years ago. The eolian $A$ horizon on unit $Q 2$, its absence on unit $Q 1$ and the presence of desert pavement on unit $Q 2$, and its lack on unit QI indicate that these events took place before deposit of unit Q1. Age dates indicate that the eolian A horizon is probably between 25,000 and 70,000 years old. An age of 27,000 to 35,000 years for the eolian A horizon is inferred from a correlation of the A horizon to a dry period of Searles Lake, California. Ages of packrat middens indicate that unit QI was deposited less than 8,000 years ago. Correlations between the NTS region and Tule Springs indicate that the age of $Q \mid$ subunits may be: $Q \mid c$, less than 12,000 and more than 7,000 or 8,000 years old; Qle (older depositional period) and Q/s probably, less than 7,000 and more than 3,300 years old; QIb, less than 4,900 and more than 140 years old; and Q la, less than 140 years old.

\section{REFERENCES CITED}

Arkley, R. J., 1963, Calculations of carbonate and water movement in soil from climatic data: Soil Science, v. 96, p. 239-246.

Bachman, G. O., and Machette, M. N., 1977, Calcic soils and calcretes in the southwestern United States: U.S. Geological Survey Open-File Report 77794, $163 \mathrm{p}$. 
Birkeland, P. W., Colman, S. M., Burke, R. M., Shroba, P. R., and Meierding, T. C., 1979, Nomenclature of alpine glacial deposits, or, What's in a name?: Geology, v. 7, p. 532-536.

Birkeland, P. W., Crandell, D. R., and Richmond, G. M., 1971, Status of correlation of Quaternary stratigraphic units in the western conterminous United States: Quaternary Research, v. 1, p. 208-227.

Bull, W. B., 1974, Geomorphic tectonic analysis of the Vidal region in Information concerning site characteristics, Vidal Nuclear Generating Station: Southern California Edison Co., 1975, appendix 2.5B, 66 p.

Carr, W. J., Dickey, D. D., and Bull, W. B., 1980, Geologic map of the Parker, Parker-NW, and parts of the Whipple Wash, Whipple Mountains SW quadrangles, California and Arizona: U.S. Geological Survey Miscellaneous Investigation Map 1-1 124, scale 1:24,000.

Denny, C. S., 1965, Alluvial fans in the Death Valley region, California and Nevada: U.S. Geological Survey Professional Paper 466, $62 \mathrm{p}$.

Gile, L. H., Peterson, F. F., and Grossman, R. B., 1966, Morphological and genetic sequences of carbonate accumulation in desert soils: Soil Science, v. 101, p. $347-360$.

Haynes, C. V., Jr., 1968, Geochronology of Late-Quaternary (sic) alluvium, in Means of correlation of Quaternary successions: Proceedings VII International Quaternary Congress, v. 8, p. 591-631.

Krumbein, W. C., and Sloss, L. L., 1955, Stratigraphy and sedimentation: San Francisco, 497 p.

Malde, H. E., and Schick, A. P., 1964, Thorne Cave, northeastern Utah: America Antiquity, v. 30, p. 60-73.

Morrison, R. B., 1967, Principles of Quaternary soil stratigraphy, in Quaternary soils: Proceedings VII International Quaternary Congress, v. 9, p. 1-70.

Morrison, R. B., 1968, Means of time-stratigraphic division and long-distance correlation of Quaternary successions, in Means of correlation of Quaternary successions: Proceedings VII International Quaternary Congress, p. $1-113$ 631 .

Smith, G. I., 1979, Subsurface stratigraphy and geochemistry of late Quaternary evaporites, Searles Lake, California: U.S. Geological Survey Professional Paper 1043, $130 \mathrm{p}$.

Swadley, W C, Map showing surficial geology of the Lathrop Wells quadrangle, Nye County, Nevada: U.S. Geological Survey Miscellaneous Investigations Map I1361 [in press].

Van Devender, T. R., and Spaulding, W. G., 1979, Development of vegetation and climate in the southwestern United States: Science, v. 204, p. 701-710. 